\title{
On the Value of Perspective about System Superiority of Chinese Socialism
}

\author{
Yong Liu \\ Department of Political Science, Yangzhou University, 225009, Yangzhou, China
}

\begin{abstract}
Scientific understanding of Chinese socialist system superiority is the basis of adhering to and developing Chinese socialist system work. Value is an important measure of Chinese socialist system superiority. The socialist system China characteristic has the value of fairness and justice and the value advantage one text. Grasp the China characteristics between the unity of science and value of the advantages of the socialist system.
\end{abstract}

Keywords-chinese socialism system superiority; value orientation

\section{INTRODUCTION}

The eighteenth National Congress of CPC points out, which the socialist system is the basic achievement China characteristics more than 90 years the party and the people's struggle, creation, accumulation, but also the fundamental guarantee for the development and progress of contemporary Chinese, embodies the characteristic and advantage Chinese characteristic socialism, must cherish, always adhere to the, continuous development. Scientific understanding of Chinese socialist system superiority is a basic work to uphold and develop Chinese socialist system. The socialist system China embodies the characteristics Chinese socialistic advantage from multiple angles and levels, of which the value is an important measure of China socialist system superiority.

\section{VALUE IS AN IMPORTANT MEASURE OF CHINESE SOCIALIST SYSTEM SUPERIORITY}

Value is the external world to meet the needs of people meaning relation category in the philosophical sense. The value of the object, refers to the usefulness and significance of the subject, the object has attributes to satisfy the requirement of the subject is affirmative, positive significance, that is the special relationship between a subject and object. Reflections on the value of things is a common phenomenon in human understanding of the world and transform the world in the process, in the active object of all human, value problem is a basic problem. That is to say, in the activities of human beings, then when people understand the objective things themselves "is what, why", will further thinking and what is the significance and role of the things to people and human development, the good or bad judgment, and then to the next step of the conscious, cognition and reconstruction activities purpose. In the materialist conception of history, values are always permeated in the objective things and practice, system design, system arrangement and system implementation is an important human activities and products, which inevitably involves value problem. Social system is a kind of subjective activity results on the development of human society, any social system contains the intrinsic value orientation of the human subject, reflect and meet the main demand relationship. The socialist system Chinese feature as a kind of social mechanism has the same basic dimension value, significance and role of this dimension reflects the Chinese socialist system has to man's development and the progress of human society.

The value of the socialist system Chinese characteristics is very important in the formation process of this system, as Deng Xiaoping points out, "we struggle for socialism, not only because of the conditions for faster development of the productive forces than capitalism, but also because only socialism can eliminate that are inherent in capitalism and other systems of exploitation, corruption and greed injustice." The socialist system Chinese characteristics not only scientific offer condition to create more productivity than capitalism, more valuable features, such as it can make the socialist society to avoid the capitalist society serious polarization, can help the socialist society all sorts of social problems will destroy the system of exploitation. The value of the socialist system China characteristics is an important dimension reflects Chinese socialist system superiority, but also an important yardstick to measure people grasp and China socialist system superiority.

The Chinese socialist system is Chinese characteristic socialism summarizes the features in the system level experience, and is also the practice of socialist Chinese characteristics of continued development; it reflects the Chinese socialist superiority from the multi-level and multi angle. The specific point of view, the socialist system Chinese features are beneficial to maintain the vitality of the party and state, to mobilize the broad masses of the people and the creative enthusiasm, initiative, all aspects of society, to liberate and develop social productive forces, to promote the overall economic and social development, to maintain and promote social equity and justice, to achieve common prosperity of all people, to focus the strength to do great things, to effectively deal with various risks and challenges on the way ahead, is conducive to safeguarding national unity, social stability, national unity. As can be seen, the socialist system Chinese characteristic advantage have both advantages of Science in line with the objective law, also accord advantage value requirements of human development, science and value are unified in the socialist system Chinese characteristic system. In the scientific understanding of China socialist system superiority, value choice, answer to the socialist system 
Chinese characteristic value orientation and value goals, value attribute of the socialist system China characteristics is an important measure of people's measure China socialist system superiority.

\section{THE VALUE ORIENTATION OF JUSTICE AND} ADVANTAGES OF THE CHINESE SOCIALIST SYSTEM

Socialism is not only a kind of thought and movement, socialism is a kind of important values and ideals. Fairness and justice is always persist firmly in pursuit of value of human society, as an advanced social system, socialism must be in their values give justice to the important position. Since from the utopian socialism into science, from theory to reality, human beings for the value of the pursuit of justice is possible, this possibility is based on the objective laws of scientific understanding of social development. Especially the socialism after the long history of the development, fairness and justice has increasingly become the primary goal of value of the socialist system, the realization of social fairness and justice is the inherent requirement of the essence of socialism. The socialist system Chinese characteristics is the concrete form of socialism in China, it is in the China socialist economic, political, cultural, social and other fields to form a mutual connection, mutual connection, mutual influence and interaction of the system, this system will realize the fairness and justice as the essential requirements.

Fairness and justice is the eternal pursuit of human society, in ancient Greece, Aristotle will give justice to the significance, "a part of justice is not a virtue, but the virtue of justice", "set of all virtue of the great". Utopian society main, "private property is the only reason numerous crimes and poverty and disaster in the world caused by the. It is not just in theory, but in practice it is not rational." In their view, private ownership is the root of the obstacle to human social fairness and justice, and only completely abolish the private ownership, social wealth can get the average distribution justice, human beings can have benefits. To realize social justice allocation is the fundamental mission of socialism, justice is the basic value of the socialist system. In Marx Engels's socialist ideals, "end must sacrifice the interests of some people to meet other people's needs", make "all people enjoy you created welfare", "so that all members of society can get all-round development". Fairness and justice as the value system of socialist ideals and principles, the socialist system is superior to the capitalist system and important aspect of socialist political legitimacy foundation.

Advantages of the Chinese socialist system superiority in the justice value are mainly reflected in the basic principle of common prosperity. Realizing common prosperity is the essential requirement of socialism; the fundamental value orientation is the socialist system Chinese characteristics. The socialist system China characteristics to Deng Xiaoping's thought of common wealth the generalization of the essence of socialism as the core, the essence of socialism is to liberate and develop productivity requirements, but also has the elimination of exploitation, eliminate polarization, implementation is collective and rich requirements, common prosperity is the fundamental principle of the essence of socialism, is also an important embodiment of socialist superiority. Common prosperity is the justice value orientation of socialist system Chinese characteristics, it has two meanings: one is the common prosperity does not mean egalitarianism, poverty is not socialism, widespread poverty is not socialism, collective and rich thought of "inequality is not scarcity" traditional wrong ideas to correct; two is the socialist system China characteristics must avoid capitalism "polarization", which is not only the essential requirement of socialism, is the socialist system of comparative advantage.

The Chinese socialist system of fairness and justice in the value orientation, not only have the basic value principle of common prosperity, still in the system mechanism has been fully embodied and implemented. And the implementation of Chinese socialist economic, political, cultural, social and other system design, arrangement have highlighted uphold fairness and justice and maintain the value of the goal of common prosperity. The basis of the socialist economic system of our country is public ownership of the means of production, namely, ownership by the whole people and collective ownership by the working people, this kind of system in the primary stage of socialist basic economic system with public ownership as the main body, various kinds of ownership economy develop jointly, the distribution system to distribution according to work as the main body, a variety of modes of distribution coexist, the in the socialist economic Chinese characteristic system of justice and the common prosperity of the stick and maintenance. At present our country is in the period of social transformation, social contradictions complex, then especially need expression of interest and the interests of the game through the effective institutional arrangements to accommodate and regulate the different interest subjects, the establishment of social interest coordination mechanism, the formation of a fair and reasonable social relations.

\section{The VAlue ORIENTATION OF PEOPLE'S ORIENTED OF THE CHINESE SOCIALIST SYSTEM}

Value is the core of the need of people, the key value is the value of the subject and to meet the needs of the advantages of the socialist system, the final value of Chinese characteristics reflected in the level of development and the people. The value of advantages of the socialist system China characteristics is people-oriented, which is reflected in the report of the Seventeenth Party Congress is very obvious, namely "to always achieve, maintain, develop the fundamental interests of the people of all the work of the party and the country as the starting point and the foothold, respect the principal position of the people, play the people's pioneering spirit, guarantee the rights of the people, and take the road of common prosperity, and promote the all-round development of people, ensure that development is for the people, rely on the development of achievement of people, development shared by the people." Humanism is the basic value principle of CPC; important value advantage is the socialist system China characteristics.

In the history of socialist system Chinese characteristics, "people-oriented" is always the most basic value. In the cause of socialism with China characteristics open, Deng Xiaoping 
stressed the need to put the interests of the masses in the first place, socialism must according to the favorable conditions to accelerate the development of productivity now, so that the people's material life better, so that the people's cultural life, spiritual outlook is better, the socialist economy is based on public ownership the production is based, in order to maximize meet the people's material, cultural needs. With Jiang Zemin as the core of the China Communists to represent the fundamental interests of the overwhelming majority of the people China, will be the development of advanced productivity and advanced culture as the basic conditions of realizing the fundamental interests of the masses, will be "people-oriented" as "the basic value orientation of the important thought of" Three Represents ", to meet the requirements of the" Three Represents ", the most fundamental is to continue to achieve good, development, and safeguarding the fundamental interests of the overwhelming majority of the people, this is the construction of socialist Chinese starting point and end point in all the work. With $\mathrm{Hu}$ Jintao as general secretary of the Communist Party of Chinese people explicitly put forward the "people-oriented" scientific concept of development as the core and write Chinese Communist Party Constitution, will be people-oriented as the party's nature and embodies the fundamental purpose of put one's heart and soul into serving the people, as the highest standard guidelines, evaluation, inspection of all the party's activities.

Chinese socialist system of "people-oriented" values, the first is to maintain the people's principal position, defend the fundamental interests of the people. The people are the makers of history, the main force of socialism's Chinese characteristics, "Chinese things can be done, the socialist reform and opening up can insist, economy can develop faster, the country can long period of stability, in a certain sense, the key lies in person." China socialist system "people-oriented" value orientation, but also in promoting the comprehensive development of human freedom Chinese characteristic socialism. The new socialist society is "from each individual's comprehensive and free development as the basic principle of social forms". The comprehensive development of human freedom is the ultimate value goal of socialism; the ultimate goal is the socialist system China characteristics. The free and comprehensive development of human aspects of the full development is to realize people's ability, give full play to the potential, there are inherent "force of nature" of man, including the natural quality and mental quality (such as people's physical, health, life and knowledge, love, meaning the full development, etc.) fully developed some of the social intercourse, the more important is the development of man's all-round development is not a small number of people but a social member's comprehensive and free development. Therefore, advantages of the socialist system China characteristics in value must be free to promote people's all-round development, human development as the basic value target of socialism system China characteristics.

\section{UNDERSTANDING THE CHINESE SOCIALIST SYSTEM IN THE UNITY OF SCIENCE AND VALUE}

Any knowledge and practical activities are restricted by the scientific and value yardstick, science and value are always of the same people to understand and transform the world events. About the socialist system China characteristics and advantages, we attach great importance to its value, does not mean that the science to deny or ignore this system, must grasp China characteristics in the unity of science and value of the advantages of the socialist system. In the socialist system Chinese characteristics, science and value are inseparable and dialectical unity together, scientific socialism China characteristics is the premise of value, value is the scientific objective, the great practice of both unity and Chinese socialism.

The advantage of scientific socialist system China characteristic is China socialist system to follow the objective law of development of human society, in theory, scientific representation of the Communist Party of the law, the laws of socialist construction and human social development, socialist system superiority China characteristic is decided by the objective law. Contradiction of socialist system Chinese characteristics meet the productive forces and production relations, adhere to the liberation and development of productivity as the fundamental requirements, to seek truth from facts, proceed from reality in everything. However, the socialist system Chinese characteristic scientific service to its value, the fundamental purpose of the development of socialist productive forces of the China characteristic is to achieve the common prosperity of all the people, to promote the comprehensive development of human freedom. The value of the socialist system China contains the characteristics of system development and improvement of the guiding ideology and the spiritual support, although the socialist system is the inevitable outcome of the productivity develops into certain stage, however, the socialist system and not with the development of productive forces and formed spontaneously, the socialist system has its special value, it is the proletariat to realization of self liberation and human liberation and live a better life and consciously set up system, as the "Communist Manifesto" in the classic paper, "all the movements of the past are few, or for the interests of the minority sports. The proletarian movement is the overwhelming majority of the people, for the vast majority of people's interests and independent movement ", the pursuit of value to provide the motive power for the socialist system and the development of the cause of socialism.

In the human understanding and transforming the world's activities, the knowledge of the truth and value creation are the two essential target, run parallel. The socialist system China characteristic is the unity of the regularity and purpose, is the unity of science and value, adhere to and develop China socialist system, should follow the objective law, the China socialist system with regularity and scientific, but also to achieve the fundamental interests of the people, so that Chinese socialist system with the purpose and value. Only grasp the unity of science and value of the Chinese socialist system, you can fully understand the Chinese socialist system superiority. 


\section{ACKNOWLEDGMENT}

This study was supported by a grant from the National Social Science Foundation of China (No.11@ZH019), Humanities and Social Science Foundation of Ministry of education (No.13YJC710031) and Social Science Foundation of Jiangsu Province (No.13MLB005)

\section{REFERENCES}

[1] Deng Xiaoping, Deng Xiaoping anthology, People's Publishing House, vol3, 1993.

[2] Marx and Engels, Selected works of Marx and Engels, People's Publishing House, vol1, 1995. 